\title{
An Exploration of Rhizobium from Green Gram Root Nodules in the three Agroclimatic Zones of Karnataka, India
}

\author{
Gurubasayya Kallimath $^{1^{*}}$ and C.R. Patil ${ }^{2}$ \\ ${ }^{1}$ Department of Agricultural Microbiology, College of Agriculture, Dharwad, \\ Karnataka, India \\ ${ }^{2}$ Department of Agriculture Microbiology, AC, Dharwad, UAS, Dharwad, Karnataka, India \\ *Corresponding author
}

\section{A B S T R A C T}

Keywords

Rhizobium,

Nitrogen fixation,

Antagonistic

activity, $\mathrm{HCN}$ and

siderophore

Article Info

Accepted:

16 February 2018

Available Online:

10 March 2018
An investigation was carried out to isolate plant growth promoting rhizobacteria from (PGPR) the rhizosphere, endorhizosphere and root nodules of green gram soil samples collected from three different agro climatic zones of Karnataka. A total of 29 rhizobial isolates from nodules isolated in that based on morphology and Gram reaction these strains were tentatively grouped as Rhizobium (29). All isolates were evaluated for eight plant growth promotional traits under in vitro. In particularly isolates 2DWRR and 9DWRR fixed respectively 5.07 and $4.46 \mathrm{mg} \mathrm{N}_{2} \mathrm{~g}^{-1}$ of carbon utilized respectively. Isolate $12 \mathrm{UKR}$ produced $13.61 \mu \mathrm{g} \mathrm{ml}^{-1}$ IAA. Isolate $10 \mathrm{DWRR}$ produced $7.72 \mu \mathrm{g}$ GA per $25 \mathrm{ml}$ respectively. Under in vitro studies some isolates inhibited plant pathogens tested. Isolate 2UKR recorded the maximum zinc solubilization $(7.00 \mathrm{~mm})$ followed by $2 \mathrm{DWRR}$. Two isolates of Rhizobium namely; 2DWRR and 9DWRR were efficient in traits like nitrogen fixation and nodule formation on green gram. The study helped to identify isolate 2DWRR, 9DWRR as potential PGPR strains for green gram.

\section{Introduction}

Rhizobium species have been defined in terms of cross-inoculation groups among legumes. However, it is generally recognized that this approach is inadequate since crossinoculation groups are not mutually exclusive and plant specificity is probably a plasmid borne character. Rhizobium invades the root hairs of green gram and result in the formation of nodules, where free air nitrogen is fixed. These bacteria, although present in most of the soils vary in number, effectiveness in nodulation and $\mathrm{N}_{2}$-fixation. It has been argued that usual native soil rhizobial populations are inadequate and are ineffective in biological nitrogen fixation. To ensure an optimum rhizobial population in the rhizosphere, seed inoculation of legumes with an efficient rhizobial strain is necessary. This helps improve nodulation, $\mathrm{N}_{2}$-fixation, solicit improved growth and yield of leguminous crops (Henzell, 1988). Green gram (Vigna radiata $\mathrm{L}$.) also known as mung bean, is a well known pulse crop of India. Mungbean is digestible, high in protein (22-24\%) and does 
not cause flatulence like many other legumes. It is rich in vitamins such as $\mathrm{A}, \mathrm{B}, \mathrm{C}$, niacin, and minerals such as potassium, phosphorus and calcium, which are necessary for human body (Rattanawongsa, 1993). Owing to all these characteristics it is a good substitute for animal protein and forms a balanced diet when it is taken with cereals. Although, this crop is capable of fixing atmospheric nitrogen through Rhizobium species living in root nodules, under our agro-ecological conditions, the nodulation of mungbean by native Rhizobia is poor and is a major cause for its lower yield. Further, inoculation of mungbean with Rhizobium spp. has shown increased plant height, leaf area, photosynthetic rate and dry matter production (Thakur and Panwar, 1995).

Rhizobia fix substantial quantities of nitrogen symbiotically between 80 to $150 \mathrm{~kg} \mathrm{~N} \mathrm{ha}^{-1}$ in 90 days. This emphasizes the potential and need for isolating and identifying efficient strains of rhizobia for inoculating green gram. The present study was conducted to Rhizobium from root nodules on green gram caused by Rhizobia present in samples collected from different agro climatic zones namely zone 3, 8 and 9 of Karnataka. These three zones have most suitable conditions for green gram like black and read soil and warm humid conditions and also within temperature range of $25-35{ }^{\circ} \mathrm{C}$, with moderate rains.

\section{Materials and Methods}

\section{Isolation of Rhizobium}

Legume rhizosphere soil samples were collected from three different agro climatic zones of northern Karnataka (Zone 3, 8 and 9). Two kilograms of collected soil sample was weighed and placed in plastic pots of three kilogram capacity. Green gram seeds of variety DGGV-2 were surface sterilized by dipping in 70 per cent alcohol for three minutes and rinsed three times in sterile distilled water and sown separately in each pot. Three plants were maintained per pot. The plants were allowed to grow by maintaining moisture at field capacity in pots. Plants were uprooted to collect root nodules at 30 days after sowing (DAS). The nodules were surface sterilized by dipping in 70 per cent alcohol for three minutes and rinsed three times in sterile distilled water before using them for isolating Rhizobium. The surface sterilized nodules were crushed in sterile pestle and mortar. The crushed sample was plated on Yeast Extract Manitol Agar medium and incubated at $30{ }^{\circ} \mathrm{C}$. The growth of the colonies was observed to pick prominent colony types for purification.

\section{Purification and maintenance of isolates}

Twenty nine isolates of Rhizobium were obtained from nodules. The colonies were purified by four way streak plate method and the pure cultures were maintained as slants and stored at $-20{ }^{\circ} \mathrm{C}$ at the, Institute of Organic Farming, University of Agricultural Sciences, Dharwad. All the 29 isolates were checked for their purity and then studied for the colony morphology, colour characteristics. The cell shape and Gram reactions were also recorded as per the standard procedures given by Barthalomew and Mittewar (1950) and Anon (1957). The microscopic studies, using Olympus SZX2 motorized microscope system were made.

\section{Characterization of Rhizobium isolates for functional diversity}

\section{Testing of isolates for free living nitrogen fixation}

The petri plates poured with sterilized Norris $\mathrm{N}$-free agar medium were separately spotted with $10 \square 1$ of overnight grown cultures of each isolate and incubated at $28 \pm 2{ }^{\circ} \mathrm{C}$ for 48 
h. The observations on ability of the isolates to grow on $\mathrm{N}$-free medium were recorded. The isolates which showed growth on $\mathrm{N}$-free media were scored as positive for nitrogen fixation the colony were noted as nitrogen fixers. As all 29 isolates were found positive they were further studied for their ability to fix nitrogen under in vitro.

\section{In vitro nitrogen $\left(\mathbf{N}_{2}\right)$ fixation by isolates}

The isolates positive for nitrogen fixation on Norris $\mathrm{N}$-free agar medium were subjected to quantification of nitrogen fixation in Norris $\mathrm{N}$-free broth. All 29 isolates were subjected for quantitative estimation of the amount of nitrogen fixed in the broth culture by Microkjeldahl method (Bremner and Mulvaney, 1982). Each of the 29 isolates was grown overnight in $\mathrm{N}$-free broth by inoculating one $\mathrm{ml}$ of the culture to $50 \mathrm{ml}$ fresh sterile Norris N-free broth in $100 \mathrm{ml}$ conical flask. Two replications were maintained for each isolate in this estimation.

\section{Plant infection assay for Rhizobia}

All the 29 rhizobial strains and also reference strains; NC-92 and SB-120 obtained from the Institute of Organic Farming, University of Agricultural Sciences, Dharwad were studied for nodulating selected six different legume crops such as green gram (variety DGGV-2), black gram (variety DGGV-5), groundnut (variety GPBD-4), cowpea (variety DC-15), chickpea (variety JG-11) and soybean (variety Dsb-21) following plant infection technique by Shamseldin et al., (2015). The nodulation assays were performed in Leonard jars with sterile fine sand (2 $\mathrm{mm}$ size) and $\mathrm{N}$-free nutrient solution.

\section{Production of growth promoting} substances by the Rhizobium isolates

The isolates were examined for the production of indole acetic acid (IAA) and
Gibberellic acid (GA) on Luria's agar supplemented with Sodium dodecyl sulphate (SDS @ $0.01 \%$ ) and glycerol (1\%).

\section{Antagonistic activity of the Rhizobium}

All the 29 isolates were subjected to in vitro assay for their antagonistic activity against four fungal plant pathogens, viz., Fusarium oxysporum f. sp. carthami (Klisiewicz and Houston) causing wilt, Curvularia lunata (wakker) causing grain mold, Colletotrichum capsisi causing leaf blight and Sclerotium rolfsii.

In vitro antagonistic activity of the isolates was also tested against two bacterial plant pathogens viz., Xanthomonas axonopodis pv. punicae (Hingorani and Singh), causing bacterial blight of pomegranate, Ralstonia solanacearum (Smith) causing bacterial wilt of solanaceous crops. The dual inoculation technique suggested by Sakthivel and Gnanamanickam (1987) was used to study the antagonistic activity of the rhizobium isolates against the above plant pathogens in vitro.

\section{Production of $\mathrm{HCN}$ and siderophore}

Production of hydrogen cyanide by PGPR isolates in vitro was tested using picric acid assay and siderophore production was tested by Chrome Azurol S agar assay.

\section{Screening for zinc and potassium solubilization}

All the 29 isolates obtained were tested for their ability to solubilize insoluble inorganic zinc on mineral salt medium (Di Simine et al., 1998) supplemented with $\mathrm{ZnO}$ (AR) (0.25\%) similarly potassium solubilisation ability of isolates was studied on plates containing modified Aleksandrov medium following the spot test method of Sugumaran and Janarthanam (2007). 


\section{Results and Discussion}

Plant Growth Promoting Rhizobacteria (PGPR) is a group of bacteria that can actively colonize plant roots and can enhance plant growth by using different mechanisms. It is reported that research on PGPR has been increasing since the term was first used by Kloepper in the late 1970s (Vessey, 2003). Recent progress in our understanding on the diversity of PGPR in the rhizosphere, their colonization ability and mechanism of action, has facilitated their application as a reliable component in the management of sustainable agricultural system (Bhattacharya and Jha, 2012). The present work aimed at characterizing Rhizobium isolates of green gram (Vigna radiata) and identify their functional traits useful in agriculture was aimed at developing Rhizobial biofertilizer which is locally adopted and functional efficient for legumes in general and green gram in particular. A total of 29 isolates were obtained in this study, from three distinct agro climatic zones of Karnataka covering global hot spot in Western Ghats.

All 29 isolates obtained from root nodules on Yeast Extract Monitol Agar were examined for colony morphology, cell morphology and Gram reaction (Table 1). There were marginal variations in colony morphology as all the isolates showed creamy coloured, circular colonies. All isolates were rod shaped and gram negative in their reaction. It appears that studying the Gram reaction of Rhizobium is an essential preliminary attempt which helps to place them in relevant taxonomic group. Among the bacterial shapes, rod shaped bacteria were more abundant than the other morphological forms.

All 29 colonies appeared white translucent on yeast extract mannitol agar with congo red. Phenotypic characterization of rhizobia was emphasized by earlier studies (Wolde-meskel et al., 2004). Similar, observations of rhizobial isolates on YEMA plates were made in previous studies of Shetta et al., (2011); Kingchan and Chidkamon (2014) which indicated that the methodologies adopted were adequate to explore diversity that existed in samples collected from three agro climatic zones.

All 29 isolates were studied for their functional diversity relevant to application in agriculture, such as; $\mathrm{N}_{2}$ fixation, plant infection test, production of plant growth promoting substance, antagonistic activity against plant pathogens, mechanism of pathogen inhibition, zinc and potash solubilisation.

Twenty nine isolates which showed substantial growth on Norris $\mathrm{N}$-free medium were subjected to quantitative estimation of nitrogen fixation in vitro in Norris $\mathrm{N}$-free broth. The amount of nitrogen fixed ranged from 2.42 to $5.07 \mathrm{mg} \mathrm{N} \mathrm{N}_{2}$ per gm of carbon utilized. Isolate $2 \mathrm{DWRR}$ fixed significantly higher amount of nitrogen fixation $(5.07 \mathrm{mg}$ $\mathrm{N}_{2} / \mathrm{g}$ of carbon utilized) than all other isolates under in vitro. The isolates; 9DWRR, 1DWRR, 2UKR and 3DWRR fixed 4.46, $4.08,3.88$ and $3.85 \mathrm{mg} \mathrm{N}_{2} / \mathrm{g}$ of carbon utilized respectively and were significantly superior to the rest of the isolates (Table 2).

Reference strain SB120 and NC92 respectively fixed 5.07 and $4.92 \mathrm{mg} \mathrm{N}_{2}$ per $\mathrm{g}$ of carbon utilized. As reported by Boddey and Dobereiner (1995) the amount of nitrogen fixed by diazotrophs due to nitrogenase enzyme was known to vary among the isolates. Similarly Abdullahi and Ken (2000) observed specificity for $\mathrm{N}_{2}$ fixation and nodulation among the legumes. In their study rhizobial isolates of $C$. calothyrsus, G. sepium and $L$. leucocephala were able to effectively cross-nodulate each other hosts as well as a number of other species. These efforts clearly resulted in identifying two isolates from green gram nodules with higher potential for 
nitrogen fixation. The nitrogen fixing efficiency of other diazotrophs such as Rhizobium, Azospirillum, Bacillus and Enterobacter isolates had been evaluated earlier (Boddey and Dobereiner, 1995; Santosh 2006; Kumar et al., 2014) and was found to vary greatly. The nitrogen fixing ability of Azospirillum isolates from grasses was found to vary from $3.42 \mathrm{mg} \mathrm{N} / \mathrm{g}$ to 61.12 $\mathrm{mg} \mathrm{N} / \mathrm{g}$ carbon source consumed (Santosh 2006). Kanimozhi and Panneerselvam (2010) recorded 15.6 and $3.3 \mathrm{mg}$ nitrogen fixed per gram of malate respectively by $A$. brasilense and $A$. halopreferens isolated from the soils of Thanjavur district.

Twenty nine rhizobial strains were isolated from surface sterilized nodules of green gram. All of these isolates and also reference strain NC-92 and SB-120 were examined in plant infection test for selecting the strains that are able to nodulate six different legume crops. Ability to nodulate legume crops such as green gram (variety DGGV-2), black gram (variety DGGV-5), groundnut (variety GPBD-4), cowpea (variety DC-15), chickpea (variety JG-11) and soybean (variety DSB21). The result indicated that in green gram 15 isolates, in black gram nine isolates and in cowpea three isolates formed nodules (Table 2). These isolates; 1DWR, 5DWR, 6DWR, 7DWR, 8DWR, 9DWR, 10DWR, 13DWR, 1UKR，5UKR，7UKR， 8UKR， 10UKR, 12UKR, 1GDGR, 3GDGR, 6GDGR and 4DWR formed nodules in one or more than one legume crops. No rhizobial isolate formed nodules on three of the legumes used namely chickpea, soybean and groundnut.

Isolates 2DWRR and 9DWRR showed higher nodulating efficiency as compared to other isolates and reference strains NC-92 and SB120. The nodules formed by standard strain NC-92 in green gram and black gram on an average ranged between 1.5 and 1 per plant respectively. It was interesting to observe that isolate 9DWRR formed nodules in green gram (average 1.5/plant), blackgram (average 1/plant) and cowpea (average 4.5/plant). This was the only isolate which showed nodulation in all these three legumes. The highest average numbers of nodules formed by the isolate 2DWRR were 4.5 and 6.5 per plant respectively in green gram and cowpea. Another two isolates 4DWRR and 8UKR formed nodules in both green gram and black gram. Eleven isolates failed to form nodules on these six legume crops. Further, the nodules formed on roots were bold and on cutting them open appeared pink in colour which suggested that they were effective nodules. Wange (1989) obtained effective symbiosis between rhizobia from Acacia with peanut and cowpea.

Cross inoculation experiments between rhizobial isolated from Acacia and Prosopis revealed that their symbiosis with Medicago sativa, Phaseolus vulgaris and Vicia faba (Zhang et al., 1991) were successful. In earlier reports (Habish and Khairi., 1968) no cross-inoculation occurred between strains of cicer-Rhizobium and members of legume groups including Sesbania. Studies of Duhoux et al, (1986) reported that Albizia lebbeck was nodulated only by Bradyrhizobium. Rhizobia from Albizia lebbeck did not infect Vigna mungo and Vigna radiata. Similarly from all these studies and from reports of Gaur (1975), Saubert and Scheffler (1967), to obtain a Rhizobium capable of nodulating a derived legume, conducting plant infection test with a number of legumes of choice and isolates of rhizobia could be inevitable and it is the most common and useful way of forming cross inoculation groups for newer isolates.

The isolates were qualitatively examined for the production of Indole acetic acid (IAA) and Gibberellic acid (GA). Based on the development of red colour on the filter paper or green fluorescence under UV light, it was observed that all the 29 isolates were positive 
for IAA and GA production. There were only seven isolates with intense red colour which were further screened for of IAA and GA production under in vitro. All the isolates produced both IAA and GA but they differed significantly with respect to the amount of IAA and GA produced. The amount of IAA and GA produced by the seven isolates were determined at $7^{\text {th }}$ day after inoculation (DAI) and the values ranged from 2.05 to $13.61 \mu \mathrm{g}$ $\mathrm{ml}^{-1}$ broth. Among the isolates examined, 12UKR produced maximum amount of IAA (13.61 $\mu \mathrm{g} \mathrm{ml}^{-1}$ broth), followed by 8UKR (7.79 $\mu \mathrm{g} \mathrm{ml}^{-1}$ broth) (Table 3). Similar results were found with Rhizobium sp. isolated from the root nodules of a leguminous pulse Cajanus cajan; which was able to produce 99.7 microgram of IAA $/ \mathrm{ml}$ in basal medium supplemented with L-tryptophan (Datta and Basu, 2000).

Patten and Glick (1996) however observed that the level of expression of IAA production was depended on the biosynthetic pathway, the location of genes involved and the presence of enzymes that could convert active free IAA into an inactive conjugated form. In this study rhizobial isolates with considerable amount of IAA and GA production could be identified.

Gibberellic acid is a class of phytohormone most commonly associated with modifying plant morphology by the extension of plant tissue, particularly the stem tissue (Salisbury, 1994). The amount of GA produced by the isolates ranged from 1.62 to $7.72 \mu \mathrm{g}$ per 25 $\mathrm{ml}$ broth. Among the isolates; 10DWRR produced the maximum amount of GA (7.73 $\mu \mathrm{g}$ per $25 \mathrm{ml}$ broth), followed by $8 \mathrm{UKR}$ (6.35 $\mu \mathrm{g}$ per $25 \mathrm{ml}$ broth). While two isolates produced GA quantities more than $5 \mu \mathrm{g}$ per $25 \mathrm{ml}$ broth, three isolates produced less than $5 \mu \mathrm{g}$ per $25 \mathrm{ml}$ broth (Table 3). Similarly, Lenin and Jayanti (2012) reported production of $\mathrm{GA}_{3}$ by isolates of Pseudomonas, Bacillus and Azotobacter to tune the of 6.21 to 6.80 , 6.1 to 6.14 and $4.25 \mu \mathrm{g}$ per $25 \mathrm{ml}$ broth respectively. This functional property of Rhizobial isolates is useful considering their recent role as PGPRs.

The 29 isolates were tested for their ability to inhibit selected of the fungal pathogens ( $S$. rolfsii, $F$. oxysporum and $C$. capsisi and Curvelaria lunata) on PDA medium following the dual culture method (Sakthivel and Gnanamanickam, 1987).

Among the 29 isolates only one isolate 11UKR showed antagonistic activity against all the four fungal pathogens (Table 4). Earlier reports on the strains of Sinorhizobium meliloti exhibiting antagonistic activity against Fusarium oxysporum (Antoun et al., 1978) and isolates of Rhizobium antagonistic to $F$. solani f. sp. phaseoli (Buonassisi et al., 1986) and the present finding help to identify another beneficial trait of Rhizobial isolates.

Deshwal and punkajkumar (2013) reported that Rhizobium had a good potential to be used as biological control agents against some plant pathogens. With regards to the antagonistic potential against bacterial plant pathogens, 28 isolates were found inhibitory to $X$. axonopodis pv. punicae as revealed through the zone of inhibition ranging from 0.1 to $0.45 \mathrm{~cm}$. Out of these, isolates; 3GDGR $(0.45), 5$ GDGR $(0.30 \mathrm{~cm})$, were the potential antagonistic isolates while the remaining 26 isolates recorded the inhibition zone in the range of $0.10-0.20 \mathrm{~cm}$. A total of 27 isolates were antagonistic against Ralstonia solanacearum with a zone of inhibition ranging from 0.10 to $0.35 \mathrm{~cm}$ (Table 1). Out of these, 3GDGR $(0.35 \mathrm{~cm})$ and 10UKR, 7UKR, 5GDGR (All with similar inhibition of $0.25 \mathrm{~cm}$ each) were the efficient antagonists in the order of their effectiveness which were significantly superior to the rest of the isolates. 
Table.1 Characterization of Rhizobium

\begin{tabular}{|c|c|c|c|c|c|c|c|c|c|c|c|}
\hline \multirow[t]{2}{*}{$\begin{array}{l}\text { Sl. } \\
\text { No. }\end{array}$} & \multirow[t]{2}{*}{ Isolate code } & \multicolumn{2}{|c|}{$\begin{array}{c}\text { Colony } \\
\text { morphology }\end{array}$} & \multicolumn{2}{|c|}{ Cell } & \multirow{2}{*}{$\begin{array}{c}\text { Zinc } \\
\text { solubilisation } \\
\text { (Diameter in } \mathrm{mm} \text { ) }\end{array}$} & \multirow{2}{*}{$\begin{array}{c}\text { Potash } \\
\text { solubilisation } \\
\text { (Diameter in } \mathrm{mm} \text { ) }\end{array}$} & \multirow{2}{*}{$\begin{array}{c}\text { Siderophore } \\
\text { Zone of } \\
\text { coloration }(\mathrm{mm})\end{array}$} & \multirow{2}{*}{$\begin{array}{c}\text { HCN } \\
\text { Color } \\
\text { indicated }\end{array}$} & \multicolumn{2}{|c|}{$\begin{array}{c}\text { Zone of inhibition of } \\
\text { bacterial plant pathogens }\end{array}$} \\
\hline & & Colour & Shape & Shape & $\begin{array}{l}\text { Gram } \\
\text { reaction }\end{array}$ & & & & & $\begin{array}{c}\text { Ralstonia } \\
\text { solanacearum }\end{array}$ & $\begin{array}{l}\text { X.axonopodis } \\
\text { pv.Citri }\end{array}$ \\
\hline 1 & 1DWRR & Creamy & Circular & Rod & Gram -ve & 2 & 3 & 6 & +++ & 0.15 & 0.10 \\
\hline 2 & 2DWRR & Creamy & Circular & Rod & Gram -ve & 5 & 6 & 07 & +++ & 0.10 & 0.20 \\
\hline 3 & 3DWRR & Creamy & Circular & Rod & Gram -ve & 3 & 1 & 08 & + & 0.15 & 0.20 \\
\hline 4 & 4DWRR & Creamy & Circular & Rod & Gram -ve & 1 & 2 & 07 & + & 0.10 & 0.10 \\
\hline 5 & 5DWRR & Creamy & Circular & Rod & Gram -ve & 2 & 3 & 06 & - & 0.10 & 0.20 \\
\hline 6 & 6DWRR & Creamy & Circular & Rod & Gram -ve & 1 & 1 & 09 & - & 0.20 & 0.10 \\
\hline 7 & 7DWRR & Creamy & Circular & Rod & Gram -ve & - & 2 & 11 & + & 0.10 & 0.20 \\
\hline 8 & 8DWRR & Creamy & Circular & Rod & Gram -ve & 1 & 1 & 7 & + & 0.10 & 0.00 \\
\hline 9 & 9DWRR & Creamy & Circular & Rod & Gram -ve & 1 & 1 & 9 & - & 0.20 & 0.10 \\
\hline 10 & 10DWRR & Creamy & Circular & Rod & Gram -ve & - & 2 & 7 & + & 0.00 & 0.20 \\
\hline 11 & 11DWRR & Creamy & Circular & Rod & Gram -ve & 1 & 1 & 6 & + & 0.10 & 0.10 \\
\hline 12 & 12DWRR & Creamy & Circular & Rod & Gram -ve & 2 & 1 & 5 & + & 0.10 & 0.10 \\
\hline 13 & 13DWRR & Creamy & Circular & Rod & Gram -ve & - & 3 & 8 & ++ & 0.25 & 0.20 \\
\hline 14 & 14DWRR & Creamy & Circular & Rod & Gram -ve & 1 & 2 & 7 & - & 0.00 & 0.00 \\
\hline
\end{tabular}




\begin{tabular}{|c|c|c|c|c|c|c|c|c|c|c|c|}
\hline 15 & 15DWRR & Creamy & Circular & Rod & Gram -ve & 3 & 1 & 9 & + & 0.00 & 0.10 \\
\hline 16 & 1UKR & Creamy & Circular & Rod & Gram -ve & - & 1 & 8 & ++ & 0.10 & 0.10 \\
\hline 17 & 2UKR & Creamy & Circular & Rod & Gram -ve & 7 & 1 & 9 & +++ & 0.20 & 0.10 \\
\hline 18 & 4UKR & Creamy & Circular & Rod & Gram -ve & 2 & 3 & 11 & ++ & 0.10 & 0.10 \\
\hline 19 & $5 \mathrm{UKR}$ & Creamy & Circular & Rod & Gram -ve & 1 & 1 & 10 & ++ & 0.10 & 0.10 \\
\hline 20 & 6UKR & Creamy & Circular & Rod & Gram -ve & 2 & 2 & 12 & + & 0.10 & 0.10 \\
\hline 21 & 7UKR & Creamy & Circular & Rod & Gram -ve & 1 & 1 & 11 & + & 0.25 & 0.15 \\
\hline 22 & $8 \mathrm{UKR}$ & Creamy & Circular & Rod & Gram -ve & 3 & 3 & 13 & - & 0.20 & 0.20 \\
\hline 23 & 10UKR & Creamy & Circular & Rod & Gram -ve & - & 1 & 6 & - & 0.25 & 0.15 \\
\hline 24 & 11UKR & Creamy & Circular & Rod & Gram -ve & 2 & 1 & 10 & + & 0.10 & 0.10 \\
\hline 25 & 12UKR & Creamy & Circular & Rod & Gram -ve & 1 & 2 & 7 & ++ & 0.10 & 0.10 \\
\hline 26 & 1GDGR & Creamy & Circular & Rod & Gram -ve & - & 1 & 9 & + & 0.15 & 0.15 \\
\hline 27 & 3GDGR & Creamy & Circular & Rod & Gram -ve & 1 & 3 & 8 & + & 0.35 & 0.45 \\
\hline 28 & 5GDGR & Creamy & Circular & Rod & Gram -ve & 2 & 1 & 7 & - & 0.25 & 0.30 \\
\hline 29 & 6GDGR & Creamy & Circular & Rod & Gram -ve & - & 2 & 9 & - & 0.10 & 0.15 \\
\hline
\end{tabular}


Table.2 plant infection assay by Rhizobium in different legume crops

\begin{tabular}{|c|c|c|c|c|c|}
\hline \multirow{2}{*}{$\begin{array}{c}\text { Sl. } \\
\text { No. }\end{array}$} & \multirow[t]{2}{*}{ Isolate } & Green gi & ackgram & Cowpea & \multirow{2}{*}{$\begin{array}{c}\text { Nitrogen fixed } \\
\text { (mg N/g of carbon) }\end{array}$} \\
\hline & & \multicolumn{3}{|c|}{ Nodulation/plant } & \\
\hline 1 & 1DWRR & 2.5 & 0 & 1 & 4.08 \\
\hline 2 & 2DWRR & 4.5 & 0 & 6.5 & 5.07 \\
\hline 3 & 3DWRR & 0 & 0 & 0 & 3.85 \\
\hline 4 & 4DWRR & 3 & 2 & 0 & 3.76 \\
\hline 5 & 5DWRR & 1.5 & 0 & 0 & 3.23 \\
\hline 6 & 6DWRR & 3 & 0 & 0 & 3.09 \\
\hline 7 & 7DWRR & 1.5 & 0 & 0 & 3.88 \\
\hline 8 & 8DWRR & 1 & 0 & 0 & 2.53 \\
\hline 9 & 9DWRR & 1.5 & 1 & 4.5 & 4.46 \\
\hline 10 & 10DWRR & 1 & 0 & 0 & 3.79 \\
\hline 11 & 11DWRR & 0 & 0 & 0 & 3.82 \\
\hline 12 & 12DWRR & 0 & 0 & 0 & 3.23 \\
\hline 13 & 13DWRR & 1.5 & 0 & 0 & 3.18 \\
\hline 14 & 14DWRR & 0 & 0 & 0 & 3.41 \\
\hline 15 & 15DWRR & 0 & 0 & 0 & 3.79 \\
\hline 16 & 1UKR & 2.5 & 0 & 0 & 3.82 \\
\hline 17 & 2UKR & 0 & 0 & 0 & 3.88 \\
\hline 18 & 4UKR & 0 & 0 & 0 & 3.18 \\
\hline 19 & 5UKR & 0.5 & 0.5 & 0 & 3.23 \\
\hline 20 & 6UKR & 0 & 0 & 0 & 2.59 \\
\hline 21 & 7UKR & 1 & 0 & 0 & 3.79 \\
\hline 22 & 8UKR & 2.5 & 1 & 0 & 3.09 \\
\hline 23 & 10UKR & 0 & 1.5 & 0 & 3.38 \\
\hline 24 & 11UKR & 0 & 0 & 0 & 3.23 \\
\hline 25 & 12UKR & 0 & 2 & 0 & 3.32 \\
\hline 26 & 1GDGR & 1.5 & 0 & 0 & 3.70 \\
\hline 27 & 3GDGR & 0 & 1.5 & 0 & 3.23 \\
\hline 28 & 5GDGR & 0 & 0 & 0 & 3.32 \\
\hline 29 & 6GDGR & 0 & 1.5 & 0 & 3.12 \\
\hline 30 & SB120 & 0 & 0 & 0 & 4.92 \\
\hline 31 & NC92 & 1.5 & 1 & 0 & 5.07 \\
\hline 32 & Control & 0 & 0 & 0 & 0 \\
\hline & S.Em. \pm & 0.34 & 0.35 & 0.21 & 0.023 \\
\hline & C.D. @ $1 \%$ & 1.35 & 1.36 & 0.83 & 0.091 \\
\hline
\end{tabular}


Table.3 Estimation of IAA and GA produced by selected Rhizobium isolates

\begin{tabular}{|c|c|c|}
\hline Isolates & $\begin{array}{c}\text { IAA }(\mu \mathrm{g} / \mathbf{m l} \\
\text { broth })\end{array}$ & GA $(\boldsymbol{\mu g} / \mathbf{2 5} \mathbf{~ m l}$ broth $)$ \\
\hline 2DWRR & 7.48 & 5.26 \\
\hline 7DWRR & 2.05 & 4.06 \\
\hline 10DWRR & 2.39 & 7.73 \\
\hline 14DWRR & 2.23 & 2.22 \\
\hline 3UKR & 3.32 & 6.33 \\
\hline 8UKR & 7.79 & 6.35 \\
\hline 12UKR & 13.61 & 1.62 \\
\hline Control & 6.78 & 0.51 \\
\hline
\end{tabular}

Table.4 Antagonistic activity of Rhizbium isolate against selected fungal pathogenic strains

\begin{tabular}{|l|l|}
\hline \multicolumn{1}{|c|}{ pathogen } & $\begin{array}{l}\text { Per cent of inhibition (\%) by } \\
\text { 11UKR }\end{array}$ \\
\hline Sclerotium rolfsii & $47.78(45.20)$ \\
\hline F. oxysporum f.sp. carthami & $52.22(46.25)$ \\
\hline Colletotrichum Capsisi & $45.50(42.40)$ \\
\hline Curvelaria lunata & $51.16(45.65)$ \\
\hline
\end{tabular}

In vitro production of hydrogen cyanide by Rhizobium isolates was tested using picric acid assay. Voisard et al., (1989) have reported $\mathrm{HCN}$ production as a mechanism of biocontrol of plant pathogens. It was observed by Alvarez et al, (1995) that less than $1 \%$ of rhizobial isolates from tomato rhizosphere showed positive results for $\mathrm{HCN}$ production. Out of 29 isolates in present study, 21 isolates produced HCN. Further, 3 out of 21 isolates viz., 1DWRR, 2DWRR and 2UKR exhibited strong (+++) HCN production. Another four isolates were scored as moderate $(++)$ for $\mathrm{HCN}$ production whereas the remaining 13 isolates were weak HCN producers (Table 1). However some studies earlier reported that
Rhizobium isolates were relatively less efficient in HCN production, as a contrarily Rhizobium NBRI 19513 was found to completely inhibited the growth of Fusarium oxysporum, and Pythium sp. in vitro (Nautiyal, 1977).

Siderophore production by antagonistic microorganisms is believed to be a mechanism of pathogen suppression. Siderophores are usually produced by various soil microbes including actinomycetes to bind $\mathrm{Fe}^{3+}$ from the environment and make it available for its own growth beside plants utilizing these as a source of iron. All the 29 isolates were observed to produce 
siderophores; however, the zone of clearance on CAS agar ranged from $6 \mathrm{~mm}$ to $21 \mathrm{~mm}$. Five isolates; 7DWRR (11 mm), 4UKR (11 $\mathrm{mm}), 6 U K R(12 \mathrm{~mm}), 7 \mathrm{UKR}(11 \mathrm{~mm})$ and 8UKR $(21 \mathrm{~mm})$ produced zones of clearance above $10 \mathrm{~mm}$ which were significantly superior to the remaining isolates (Table 1). While, 24 isolates exhibited between 5 and 10 $\mathrm{mm}$ clearance zone on CAS agar. These observations clearly demonstrated wide variations among Rhizobium isolates in siderophore production. Rhizobium strains isolated from the root nodules of Sesbania seban (L) Merr, also showed the ability to produce hydroxamate type of siderophore (Osario et al., 2008) while Rhizobial isolate belonging to Rhizobium and Mesorhizobium $s p$. were known to produce catecholate type of siderophore (Wandersman and Delepelaire, 2004). The findings of these studies and the present study clearly demonstrate the possible plant growth promotional activity of rhizobial isolates through siderophores production.

The diameter of the zone of zinc solubilization formed by the isolates ranged from 1 to $7 \mathrm{~mm}$ at seventh day after incubation although the zones appeared on 5 day after incubation (Table 1). Among the isolates; isolate $2 \mathrm{UKR}$ recorded the maximum zinc solubilization $(7.0 \mathrm{~mm})$ followed by 2DWRR $(5.0 \mathrm{~mm})$. However, 11 isolates produced more than $1.0 \mathrm{~mm}$ zone of hydrolysis of zinc, while 11 isolates produced the least zone $(1.0 \mathrm{~mm})$ of soubilization of zinc and seven isolates recorded the zero clearance zones. The mechanisms of acquisition of the zinc by Bacillus isolates from insoluble zinc compounds as a consequence of production of organic acids of leading to solubilization of zinc and thereby influencing the bioavailability of zinc as reported by Sharma et al., (2012). However, in the present study the mechanism of zinc solubilization was not studied.
The diameter of zone of potash solubilization formed by the isolates ranged from 1.0 to 6 $\mathrm{mm}$ seventh day after incubation although the zones appeared at $5^{\text {th }}$ day after incubation (Table 1). Among the isolates 2DWRR recorded the maximum potash solubilization $(6.0 \mathrm{~mm})$. However, six isolates produced zone with more than $2.0 \mathrm{~mm}$ reflecting hydrolysis of potash. While 23 isolates produced very low zones of soubilization of zinc (1.0-2.0 $\mathrm{mm})$. Sugumaran and Janarthanam (2007) isolated K solubilizing bacteria from soil, rocks and minerals samples viz., microcline orthoclase, muscovite mica. Among the isolates, B. mucilaginosus MCRCp1 solubilized more potassium by producing slime in muscovite mica. The bacteria might produce acids, alkalis or chelants which enhance the release of elements from potassium bearing minerals such as muscovite mica. Slime production YEMA was also observed for all 29 isolates in the present study.

Overall the study revealed that some of the Rhizobium isolates (2DWRR and 9DWRR) are good candidates to be developed as bioferlizers for N2-fixation growth promotion and yield enhancement in green gram crop and can be exploited for the ecommercial production of pulses.

\section{References}

Abdullahi, B. and Ken, E. G., 2000, Symbiotic specificity of tropical tree rhizobia for host legumes. New Phytologist., 149: 495-507.

Alvarez et al, (1995) Alvarez, M. Gagne, S. and Antour, H., 1995, Effect of compost on rhizosphere microflora of potato and on incidence of Plant Growth Promoting. Rhizobacteria, Appl. Environ. Microbiol., 61: 194-199.

Anonymous, 1957, Manual of Microbiological Method. McGraw Hill Book Company Inc., New York, pp. 127.

Antoun, H., Bordeleau, L. M. and Gagnon, C., 
1978, Antagonisme entre Rhizobium meliloti et Fusarium oxysporum en relation avec l'efficacité symbiotique. Can. J. Plant Sci., 58: 75-78.

Barthalomew, J. W. and Mittewer, J., 1950, A simplified bacterial strain. Stain Tech., 25: 153.

Bhattacharyya, P. N. and Jha, D. K., 2012, Plant growth-promoting rhizobacteria (PGPR): emergence in agriculture. World $J$. Microbiol. Biotechnol., 28: 1327-1350.

Boddey, R. M. and Dobereiner. K., 1995, Nitrogen fixation associated with grasses and cereals: Recent progress and perspectives for the future. J. Fertilizer Res., 42: 241-248.

Bremner, J. M. and Mulvaney, C.S., 1982, Total nitrogen, In: A.L. Page, R.H. Miller and D.R. Keeny, (Eds.), Methods of Soil Analysis, American Society of Agronomy and Soil Science Society of America, Madison, pp. 1119-1123.

Buonassisi. A, Copeman, R., Pepin, H. and Eaton, G., 1986, Effect of Rhizobium spp. on Fusarium solani f.sp. phaseoli, Can. J. Phytopathol., 8:140-146.

Datta, C. and Basu, P. S., 2000, Indole acetic acid production by a Rhizobium species from root nodules of a leguminous shrub, Cajanus cajan. Microbiol Res., 155 (2): 123-127.

Deshwal, V. K. and Punkajkumar., 2013, Production of Plant growth promoting substance by pseudomonads. J. Academia Industrial Res., 2: 203-204.

Di Simine, C. D., Sayer, J. A. and Gadd, G. M., 1998, Solubilization of zinc phosphate by a strain of Pseudomonas fluorescens isolated from a forest soil. Biol. Fertil. Soils, 28: 87-94.

Duhoux, E., Sougoufara, B. and Dommergues, Y., 1986, Propagation of Causurina equistifolia through axillary buds of immature female inflorescence cultured in vitro. Plant Cell Reports, 3: 161-164.

Gaur, Y. D., 1975, Studies on the root nodules bacteria of Cicer arietinum L. (Chickpea). Ph. D. Thesis, University of Rajastan, Jaipur, India, p. 48.

Habish, H. A. and Khairi, M. S., 1968, Nodulation of legumes in Sudan cross inoculation groups and associated rhizobial strains. Experimental Agri., 4: 227-234.

Henzell, E.F., 1988. The role of biological nitrogen fixation research in solving problems in tropical agriculture. Pl. Soil., 108: $15-2$.

Kanimozhi, K. and Panneerselvam, A., 2010. Studies on molecular characterization of Azospirillum spp. isolated from Thanjavur District. Int. J. Appl. Biol. Pharm. Tech., 1(3): 1209-1219.

Kingchan, M. and Chidkamon, P., 2014, Isolation and characterization of Rhizobium spp. from root of legume plants species khon kaen Agr. J., 4: 157-161.

Kumar, A., Maurya, B. R. and Raghuwanshi, R., 2014, Isolation and characterization of PGPR and their effect on growth, yield and nutrient content in wheat (Triticum aestivum L.). Biocatalysis Agric. Biotechnol., 3; 121-128.

Lenin, G. and Jayanthi, M., 2012, Efficiency of plant growth promoting rhizobacteria (PGPR) on enhancement of growth, yield and nutrient content of Catharanthus roseus. Int. J. Res. Pure App. Microbiol., 2(4): 37-42.

Nautiyal, C. S., 1977, Rhizosphere competence of Pseudomonas sp. NBR 19926 and Rhizobium sp. NBR 19513 involved in suppression of chickpea Cicer arietinum L. pathogenic fungi, FEMS Microbiol. Ecol., 23: 145-148.

Osario, H., Martinez, V., Nieto, P., Holmes D. and Quatrini, R., 2008, Microbial iron management mechanisms in acidic environment. BMC Microbiol., 8: 203.

Rattanawongsa, N., 1993. The 19th International Mungbean Nursery Trial. ARC-AVRDC Training Report

Sakthivel, N. and Gnanamanickam, S. S., 1987, Evaluation of Pseudomonas fluorescens for suppression of sheath rot disease and enhancement of grain yields in rice (Oryza sativa L.). Appl. Environ. Microbiol., 47: 2056-2059.

Salisbury, F. B., 1994, The role of plant hormones. In: plant environment interactions. Ed. Wilkinson, R.E., Marcel Dekker, New York, USA, pp. 39-81.

Santosh, S., 2006, Evaluation of azide resistant 
mutants of azospirillum on maize. M.Sc. Thesis, Univ. Agril. Sci., Dharwad, India.

Saubert, S. and Scheffler, J. G., 1967, Strain variation and host specificity of Rhizobium and host specificity of Rhizobium trifolii in European clovers. $S$. Afr. J. Agric. Sci., 10: 85-94.

Shamseldin, A., Abdelkhalekb. A. A. and AboSedrac. S. A., 2015, Isolation of highly effective, super nodulating and competitive Rhizobium trains of Egyptian clover (Trifolium alexandrinum L.). Res. J. Pharma. Biol.Chem Scien., 6(4): 760780.

Sharma, S. K., Sharma, M. P., Ramesh, A. and Joshi, O. P. 2012, Characterization of zinc-solubilizing Bacillus isolates and their potential to influence zinc assimilation in soybean seeds. $J$. Microbiol. Biotechnol., 22: 352-359.

Shetta, N. D., Al-Shaharani, T. S. and Abdel-Aal, M., 2011, Identification and characterization of Rhizobium associated with woody legume trees grown under Saudi Arabia condition. AmericanEurasian J. Agric. Environ. Sci., 10 (3): 410-418.

Sugumaran, P. and Janarthanam, B., 2007, Solubilization of potassium obtaining minerals by bacteria and their effect on plant growth. World J. Agric. Sci., 3(3); 350- 355.

Tharkur, A. K. and Panwar, J. D. S., 1995. Effect of Rhizobium VAM interactions on growth and yield in mungbean (Vigna radiata $\mathrm{L}$.) under field conditions Indian J. Pl. Pathol., 38: 62-5.
Vessey, K. J., 2003, Plant growth promotion rhizobacteria as biofertilizer. Plant Soil, 25: 557-586.

Voisard, c., Keel, o., Haas, p. and Defago, g., 1989, Cyanide production by Pseudomonas fluorescens helps to suppress black root rot of tobacco under gnotobiotic condition. Eur. Microbiol. J., 8: 351-358.

Wandersman, C. and Delepelaire, P., 2004, Bacterial iron sources: From siderophores to hemophores, Annu Rev. Microbiol., 58: 611-647.

Wang, Y., Zhang, X., Zhang, H., Lu, Y., Huang, H., Dong, X., Chen, J., Dong. J., Yang, X., Hang, H. and Jiang, T., 2012, Coiledcoil networking shapes cell molecular machinery. Mol Biol Cell., 23(19): 391122.

Wange, S. S., 1989, Response of groundnut (Arachis hypogaea L.) to inoculation with strains isolated from wild arboreal legumes. J. Appl. Microbiol. Biotech., 5: 135-141.

Wolde-meskel, E., Berg, T., Peters, N. K. and Frostegard, A., 2004, Nodulation status of native woody legumes and phenotypic characteristics of associated rhizobia in soils of southern Ethiopia. Biol Fertil Soils, 40: 55-66.

Zhang, X., Harper, R., Karisto, M. and Lindstrom, K., 1991. Diversity of Rhizobium bacteria isolated from the root nodules of leguminous trees. Int. J. Systm. Bacteriol., 41: 104-113.

\section{How to cite this article:}

Gurubasayya Kallimath and Patil, C.R. 2018. An Exploration of Rhizobium from Green Gram Root Nodules in the Three Agroclimatic Zones of Karnatak. Int.J.Curr.Microbiol.App.Sci. 7(03): 2118-2130. doi: https://doi.org/10.20546/ijcmas.2018.703.249 